\title{
Moderating Earning Management: Quality of Internal Auditors, Business Strategy, and Sustainability Reporting on Economic Performance
}

\author{
Arry Eksandy ${ }^{1} \quad$ Vinola Herawaty ${ }^{2}$ \\ 1.Trisakti University Jakarta \\ 2.Trisakti University Jakarta
}

\begin{abstract}
This research aims to determine the effect of internal auditor quality, business strategy, and sustainability reporting on economic performance with moderated by earning management partially on companies kompas 100 index during the period 2013-2016. The population in this research is all companies kompas 100 index listed on Indonesia Stock Exchange during the period 2013-2016. The total samples tested were 9 companies selected by purposive sampling technique. Data type in this research use secondary data obtained from Indonesia Stock Exchange and site respectively of company being sampled. Data analysis technique use panel data regression with Eviews 9.0 program. The result indicates that internal auditor quality have a positive effect on economic performance but after moderated by earning management of internal auditor quality has no effect on economic performance. Business strategy have a positive effect on economic performance but after moderated by earning management of business strategy has a negative effect on economic performance. Sustainability reporting have no effect on economic performance but after moderated by earning management of sustainability reporting has no effect on economic performance and return on assets as control variable have a positive effect on economic performance.
\end{abstract}

Keywords: Economic performance, Internal Auditor Quality, Business Strategy, Sustainability Reporting.

DOI: $10.7176 /$ RJFA/11-2-09

Publication date: January $31^{\text {st }} 2020$

\section{Introduction}

The economic performance of the company can be seen through the annual Stock Returns within the company, the performance is seen from the perspective of the capital market through annual stock returns or the rate of stock returns on investments made by investors. Economic performance can be judged to be better if the rate of return on shares is good, which can provide high trust to investors to invest their shares in companies related to this can signal to potential investors to invest their shares so that it can provide convenience for companies in obtaining additional capital for operational activities (Wulandari, 2013).

There are factors that influence economic performance including the quality of internal auditors, business strategies, sustainability report and Earning Management. According to Agoes (2004) in Rosnidah (2013: 301), said that internal audit is an examination carried out by the company's internal auditor, both on the company's financial statements and accounting records, as well as compliance with predetermined top management policies and adherence to government regulations and provisions of applicable professional ties. Internal auditors conduct studies, evaluate and provide recommendations independently and objectively to the activities of the company or organization so that the organization can achieve its objectives.

According to Rosnidah (2013: 301), Audit quality is the probability that the auditor is able to disclose and report a violation in the client's accounting information system. But the audit quality of internal auditors is still in the spotlight because internal auditors are within the organization and are paid by the organization so that the independence of internal auditors is sometimes still in doubt (Rosnidah, 2013). According to Rosnidah (2013) stated that as an internal company, then some of the activities in the audit process carried out might be more in favor of the benefits obtained by the company that allow it to cover up any unfavorable company activities.

So it can be concluded that the quality of good internal auditors will describe the economic performance in the company will be good. It can be seen from the financial statements that have been audited by an independent auditor not separated from the contribution of an internal auditor. Financial statements are one means of information to assess the health or failure of a company. These audited financial statements will provide additional trust to investors and prospective investors that the financial statements presented are in accordance with generally accepted standards. So an auditor, especially internal auditor, must show his quality in carrying out the audit process and its quality as an auditor.

Talking about the role of managers is inseparable from their role in determining the company's business strategy. In its capacity as a provider of financial statements on the one hand as a determinant of the company's business strategy, the quality of earnings that exist in the company is potentially also a function of business strategy (Widyasari et al, 2017). The company's business strategy affects all company activities because all business process activities, operational activities, and transactions carried out and all business decisions made by managers 
must be in line with business strategies (Arieftiara et al, 2013).

Research on business strategies is generally about the effect of business strategies on tax avoidance as research conducted by Arieftiara et al. in 2013. This study uses two types of business strategies, namely prospector and defender of Miles and Snow typology (1978) (Arieftiara et al, 2013: 6). Prospector is a company that is committed to innovation and looking for new market opportunities (Widyasari, Harindahyani, and Rudiawarni, 2017). Defender focuses on the efficiency of production and distribution of goods or services. They maintain the current market rather than looking for new market opportunities (Miles \& Snow, 1978 in Houqe et al, 2013). Defender focuses on efficiency and not on innovation (Wardani and Isabela, 2017). Defender has the motivation to maintain his reputation as a stable company that tends to meet investor expectations. While prospectors tend to prioritize their interests in innovating and seeking new market opportunities, resulting in lower fulfillment of investor expectations (Widyasari et al, 2017).

From the explanation of the two types of business strategies according to Miles and Snow (1978) it is known that business strategy defenders and prospectors have very different directions in improving the economic performance of a company. The defender strategy, for example, if a company prefers to carry out a defender business strategy by issuing products that follow the competitor's market share, can be advantageous in terms of the company's stability in the eyes of its investors. But if the company chooses to conduct a business strategy prospector who innovates in creating a product that is not the same as a competitor's market, this is permitted, but has a high risk if the new innovation is issued and not accepted by the market share, the company must be prepared to bear unwanted risks but if the innovation is accepted in its market share, this can be profitable for the company and increase economic performance (economic performance) of the company, especially if the innovation can make the company become a company that dominates market share with similar products.

According to Pardede (2014), the issue of sustainability begins with the issue of global warming and environmental damage that is increasingly happening throughout the world. At first this sustainability was a social issue, which subsequently developed into a strategic issue for the company. Companies should not only report on the condition of the company in terms of profits, but also from the social and environmental aspects.

According to Pardede (2014), Sustainability reporting is the practice of measuring, expressing, and accountability to internal and external stakeholders on organizational performance towards sustainability goals. Disclosure of sustainability reports as a form of voluntary disclosure that is expected to increase transparency of the company. Previous researchers have shown how the level of disclosure can provide financial benefits to the company. The higher the level of disclosure of continuous reports, the greater the level of transparency of the company will indicate an increase in corporate governance (Pardede, 2014). Good corporate governance will affect the reflection that is good for the company or activities that exist in the company. This will provide a role to improve economic performance within the company.

Research on factors that influence economic performance began to be carried out by many researchers. The renewal of the research carried out is one of them by using the element of earnings management as a moderating variable. According to Sulistyanto (2008: 6), earnings management is defined as the efforts of company managers to interpret or influence information in financial statements with the aim of tricking stakeholders who want to know the performance and financial conditions. Actions of earnings management are actually based on various objectives and purposes contained therein. This means that earnings management actions carried out contain certain motivations, because the level of profits or profits obtained are often associated with management performance (Timuriana and Muhamad, 2015: 13). Therefore, management often takes action so that the financial statements presented look good with the earnings management method.

Management, which is assessed for its achievements in generating profits, will tend to manage earnings opportunistically (Mahiswari and Nugroho, 2014: 01). This results in a decrease in the level of economic performance (economic performance) as a result of earnings management practices based on the opportunistic behavior of a manager.

\section{Theory Review}

\subsection{Stewardship Theory}

This stewardship theory states that there is no relation between common problems that occur with management motivation. Given the absence of internal motivational problems among executives, the question is how far executives can achieve the good corporate performance they aspire to. Thus, the theory of stewardship occurs because there are differences in performance arising from structural situations where executive management facilitates effective actions (Donaldson and Davis, 1991). The problem that occurs is whether the organizational structure helps executives to formulate and implement plans for good corporate performance (Donaldson 1985). This structure will facilitate objectives as long as they provide clear and consistent expectations and empower and empower senior management (Donaldson and Davis, 1991). 


\subsection{Positive Accounting Theory}

This theory was pioneered by Watts and Zimmerman (1989) who explained that certain economic factors can be related to the behavior of managers or financial statement makers. There are three specific hypotheses that are most often tested are the bonus plan hypothesis, the debt or equity hypothesis, and the poitical cost hypothesis. The relationship of positive accounting theory with economic performance lies in the attitude of management that seeks to use capabilities, accounting knowledge, accounting policies to look forward to the economic performance that will occur in the future based on the three hypotheses in the positive accounting theory.

\subsection{Economic Performance}

Economic performance (economic performance) is a description of the financial condition of a company and company performance analyzed by financial analysis tools, so that it can be known about the good or bad financial condition of a company that reflects work performance in a certain period. (Wulandari and Hidayah, 2013). Economic performance is expressed in a calculated scale:

$$
\mathrm{EcP}=\frac{\left(\mathrm{P}_{1}-\mathrm{P}_{0}\right)+\mathrm{Div}}{\mathrm{P}_{0}}-\mathrm{Me}_{\mathrm{RI}}
$$

Source: Widarto (2015)

Where:

EcP : Economic Performance (Economic Performance)

$P 1 \quad$ : Year-end stock price

$P 0 \quad$ : Stock price at the beginning of the year

Div : Dividend distribution

MeRI : Median annual stock return (annual median stock return).

\subsection{Quality Of Internal Auditors}

According to Junaidi and Nurdiono (2016), argues that audit quality is a concept that shows that auditors can carry out professional duties based on professional ethics, competence, and independence. According to Prawitt, Smith, and Wood (2008), the quality of internal audit is one of the four pillars of effective corporate governance, together with the audit committee of the board of directors, executive management, and external auditors. According to Rosnidah (2013), there are four measurement methods in determining the quality of internal audit including competence, independence, professionalism, and motivation. Internal auditor quality measurement methods include competence, independence, professionalism, and motivation. Therefore, the measurement of the quality of internal auditors is seen from the competencies that have been taken in terms of this education, namely seeing the professional positions that have been obtained by internal auditors. As in Auditor Competency Standards article 3 paragraph (2), the auditor must maintain his Competence through Continuing Professional Education to ensure that his Competencies are in accordance with the needs of the organization and the development of a monitoring environment. Continuing Professional Education and Training is obtained through membership and participation in professional associations, Auditor Functional Position Certification (JFA) education, conferences, seminars, courses, training programs in their own offices and participation in research projects that have substance in the field of supervision. So it can be concluded that the measurement of the quality of internal auditors is seen from how many internal auditors have obtained expertise certification. The more expertise certification obtained the more the quality of internal auditors is illustrated.

\subsection{Business Strategy}

According to Arieftiara et al (2013: 2), the company's business strategy affects all company activities because all business process activities, operational activities, and transactions carried out and all business decisions made by managers must be in line with business strategies.

Miles and Snow (1978) distinguish strategies based on organizational adaptation processes to changes in their environment, and the three main strategy typologies are Defender or defense, having behavioral characteristics, namely closing part of the total market in order to create a stable market area, defender companies try aggressively to preventing competitors from entering their land by focusing on Prospector prices, contrary to defender strategies, but both have similarities in terms of consistency overcoming three adaptive issues. The prospector's main focus is how to find and make maximum use of products, market areas and new opportunities. competitive or high quality products. To obtain the strategy value, this study uses measurements from the research of Bentley et al (2017), namely:

\section{a) RnD Intens}

$$
R n D \text { Intens }=\frac{R n D \text { Expense }}{\text { Sales }}
$$


b) Sales Effort

$$
\text { Sales Effort }=\frac{\text { Selling, general and Admin expense }}{\text { Sales }}
$$

c) Employee Intensity

$$
\text { Employee Intensity }=\frac{\text { Number of Employees }}{\text { Sales }}
$$

d) Capital Intensity

$$
\text { Capital Intensity }=\frac{\text { Property, } \text { Plant and Equipment }}{\text { Total Asset }}
$$

e) Employee Fluctuation

$$
\text { Employee Fluctuation }=\frac{\text { Employee } t-\text { Employee } t-1}{\text { Employee } t-1}
$$

f) Sales Growth

$$
\text { Sales Growth }=\frac{\text { Sales } t-\text { Sales } t-1}{\text { Sales } t-1}
$$

According to Widyasari et al (2017), each component is ranked per year - per company and given a score based on its quintile. Samples of companies that are in the order of the top quintile get a score of 5, samples of companies in the order below get a score of 4, and so on. This valuation method is given for all components except Capital Intensity. The component is given an inverse in reverse. Then the ranking score is added up, so that each observation has a minimum value of 6 and a maximum of 30. The categorization of business strategies depends on the median value of the sample. For observations that have a total value equal to or below the median, it is categorized as a defender. For observations that have a total value above the median, it is categorized as a prospector.

\subsection{Sustainability Reporting}

According to Wijayanti (2016), the sustainability reporting variable is measured by the Sustainability Report Disclosure Index (SRDI). This framework is designed to be used by various organizations of different sizes, sectors and locations. Reporting with the GRI guideline contains the general content and sector of the organization's activities (Pardede, 2014).

1) Sustainability reporting principles:

a) Principles for determining the contents of the report The principles for determining report content according to the GRI-G4 Guidelines include: Stakeholder Inclusiveness, Sustainability Context, Materiality and Completeness (Gunawan, 2015).

b) Principles for determining the quality of reports The principles for determining the quality of financial statements listed in the GRI-G4 Guidelines include: Comparability, Balance, Accuracy, Timeliness, Clarity and Reliability (Gunawan , 2015).

2) Categories of sustainability reporting disclosures Sustainability reporting according to the GRI G4 Guidelines consists of the following 6 dimensions:

a) Economy

The dimensions of economic sustainability are related to the impact of the organization on the economic situation for its stakeholders, and on the economic system at the local, national and global levels (Wijayanti, 2016).

b) Environment

The dimensions of environmental sustainability are related to the impact of organizations on living and non-living natural systems, including land, air, water, and ecosystems. Environmental categories include impacts related to inputs (such as energy and water) and output (such as emissions, effluents, and waste), including biodiversity, transportation, and impacts related to products and services, and environmental compliance and costs (Wijayanti, 2016).

c) Social

The social sustainability dimension discusses the impact the organization has on the social system in which the organization operates. Social categories contain sub-categories:

1. Labor and comfort practices

2. Human rights

3. Society 
4. Responsibility for the product.

Based on the Global Initiative Reporting (GRI) G4 Guidelines. Overall, there are 149 sustainability reporting assessment items based on the GRI G4 Guidelines. SRDI calculation is done by giving a score of 1 if an item is disclosed, and 0 if not disclosed. After scoring all items, the score is then added to get the total score for each company. The formulas for SRDI calculations are:

$$
\operatorname{SRDI}=\frac{\mathrm{n}}{\mathrm{k}}
$$

Source: Wijayanti, 2016.

Where:

SRDI = Sustainability Report Disclosure Index of the company

$\mathrm{n} \quad=$ Number of items disclosed by the company

$\mathrm{k} \quad=$ Number of items expected

\subsection{Earning Management}

Earning Management is an action or intervention carried out by managers in influencing financial information and company financial performance intentionally done to change the numbers in the financial statements in order to trick stakeholders who want to know the economic performance obtained by the company. According to Sulistyanto (2014) there are three motivations that can explain why a manager makes managerial efforts, namely capital market motivation, contractual and antitrust motivation or other government regulations.

Earnings management through discretionary revenue is measured using the estimation formula from Stubben (2010: 2) stating that discretionary revenue is the difference between actual changes in accounts receivable and predicted changes in accounts receivable based on the model. Abnormal high or low accounts receivable indicate revenue management. To benchmark against existing models, Stubben (2010) compares the capabilities of the revenue model and commonly used accrual models (Jones 1991; Dechow et al 1995; Dechow and Dichev 2002; Kothari et al 2005) to detect combinations of income and cost management (Istianingsih, 2016). The formulation of discretionary revenue used in this study is as follows:

$\Delta$ ARit $=\alpha+\beta 1 \Delta$ Rit $+\beta 2 \Delta$ Rit $\times$ SIZEit $+\beta 3 \Delta$ Rit $\times$ AGEit $+\beta 4 \Delta$ Rit $\times$ AGE_SQit $+\beta 5 \Delta$ Rit $\times$ GRR_Pit $+\beta 6 \Delta$ Rit $\times$ GRR_Nit $+\beta 7 \Delta$ Rit $\times$ GRMit $+\beta 8 \Delta$ Rit $\times$ GRM SQit $+\varepsilon$

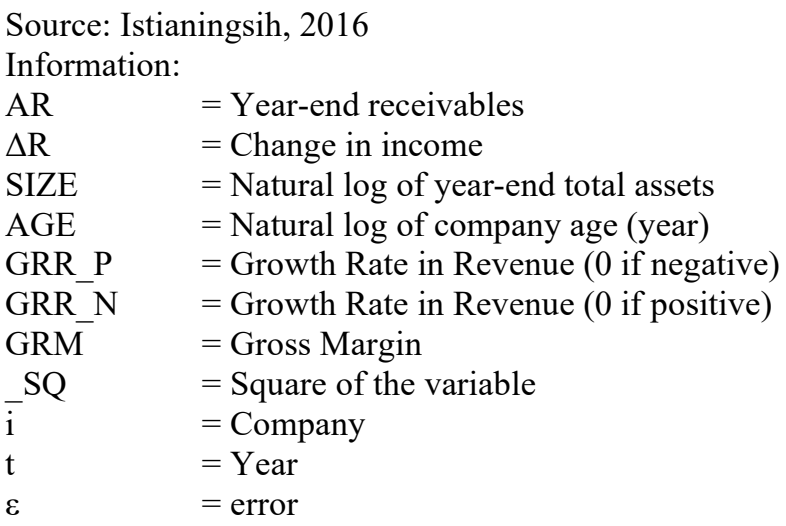

\subsection{Return On Assets}

Return on Assets is a ratio that shows how much assets contribute to creating net income. In other words, this ratio is used to measure how much net income will be generated from each rupiah of funds embedded in total assets. This ratio is calculated by dividing net income against total assets (Hery, 2017: 193).

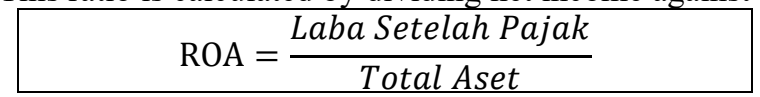

Source: Hery, 2017: 193

\subsection{Framework}

1) The Effect of Internal Auditor Quality on Economic Performance According to Rosnidah (2013: 301), Audit quality is the probability that the auditor is able to disclose and report a violation in the client's accounting information system. According to Rosnidah (2013) stated that as an internal company, then some of the activities in the audit process carried out might be more in favor of the benefits obtained by the company that allow it to cover up any unfavorable company activities. However, if the quality of the internal auditor is good, it will describe the economic performance in the company will be 
good. It can be seen from the financial statements that have been audited by an independent auditor not separated from the contribution of an internal auditor. Based on the description above, this study proposes the following hypothesis:

H1: The Quality of Internal Auditors Has a Positive Impact on Economic Performance.

2) The Effect of Business Strategy on Economic Performance

Defender's strategy makes the company prefer to do the defender's business strategy by publishing products that follow the competitor's market share, can be profitable in terms of the company's stability in the eyes of its investors. But if the company chooses to conduct a business strategy prospector that innovates in creating products that are not the same as the competing markets, this is permitted, but has a high risk if new innovations are issued and not accepted by market share, the company must be prepared to bear unwanted risks but if innovation accepted in its market share, this can be beneficial for the company and improve the economic performance (economic performance) of the company, especially if innovation can make the company a company that dominates market share with similar products. Based on the description above, this study proposes the following hypothesis:

H2: Business Strategy Has a Positive Impact on Economic Performance.

3) The Effect of Sustainability Reporting on Economic Performance

According to Pardede (2014), Sustainability reporting is the practice of measuring, expressing, and accountability to internal and external stakeholders on organizational performance towards sustainability goals. Disclosure of sustainability reports as a form of voluntary disclosure that is expected to increase transparency of the company. Previous researchers have shown how the level of disclosure can provide financial benefits to the company. The higher the level of disclosure of continuous reports, the greater the level of transparency of the company will indicate an increase in corporate governance (Pardede, 2014). Good corporate governance will affect the reflection that is good for the company or activities that exist in the company. This will provide a role to improve economic performance within the company. Based on the description above, this study proposes the following hypothesis:

H3: Sustainability Reporting Has a Positive Impact on Economic Performance.

4) The Effect of Earning Management on Economic Performance

According to Sulistyanto (2008: 6), earnings management is defined as the efforts of company managers to interpret or influence information in financial statements with the aim of tricking stakeholders who want to know the performance and financial conditions. Management, which is assessed for its achievements in generating profits, will tend to manage earnings opportunistically (Mahiswari and Nugroho, 2014: 01). This results in a decrease in the level of economic performance (economic performance) as a result of earnings management practices based on the opportunistic behavior of a manager.

H4: Earning Management has a Negative Effect on Economic Performance.

5) The Effect of Internal Auditor Quality on Economic Performance with Earning Management as Moderating Variables

The quality level of an internal auditor greatly influences the quality of financial statements. Financial reports with good quality will increase the trust in users that the financial statements presented are in accordance with generally accepted standards, besides that these financial statements are a source of information for management and stakeholders to make business decisions. Therefore, the quality of internal auditors plays a significant role in reducing the practice of earnings management from an auditor. Then it can be concluded that the economic performance of the company will decline if the quality of internal auditors is influenced by the practice of earnings management from a manager which is seen because internal auditors are and work for organizations or companies that can take partiality resulting in Earning Management can refine the Internal Auditor Quality variable. Based on the description above, this study proposes the following hypothesis:

H5: Earning Management has a Negative Effect on the Relationship of Internal Auditor Quality to Economic Performance.

6) The Effect of Business Strategy on Economic Performance with Earning Management as Moderating Variables Business strategies have a large role in stimulating managers to make earnings management (Wardani and Isabela, 2017). Like the two types of business strategies, namely the defender and prospector. The results of the Houqe et al (2013) study prove that there is a relationship between the selection of a defender business strategy and a higher level of earnings management because investor expectations of the company are also higher (Widyasari et al, 2017). Therefore, Earning Management will weaken the relationship of Business Strategy to Economic Performance. Based on the description above, this study proposes the following hypothesis:

H6: Earning Management has a Negative Effect on Business Strategy Relationships Against Economic Performance.

7) The Effect of Sustainability Reporting on Economic Performance with Earning Management as Moderating Variable 
Disclosure of Sustaianability Reporting is one report on the state of the company in the context of sustainability. So companies that publish Sustainability Reporting are companies with high transparency. This level of transparency is one of the factors of good corporate governance. Corporate governance will improve the company's economic performance. The same is true if Sustainability Reporting disclosures are used for personal purposes or benefit certain parties or called the earnings management method. The practice of earnings management will affect the quality of earnings that will be reported in financial statements, one of which is decision making for management, investors, and other stakeholders. Therefore, earnings management will weaken the Sustainability Reporting relationship to Economic Performance or economic performance. Based on the description above, this study proposes the following hypothesis:

H7: Negative Earning Management is Negative on Sustainability Report Relations Against Economic Performance.

Based on the research objectives previously described, the theoretical framework proposed in this research is as follows:

Figure 1. Research conceptual framework

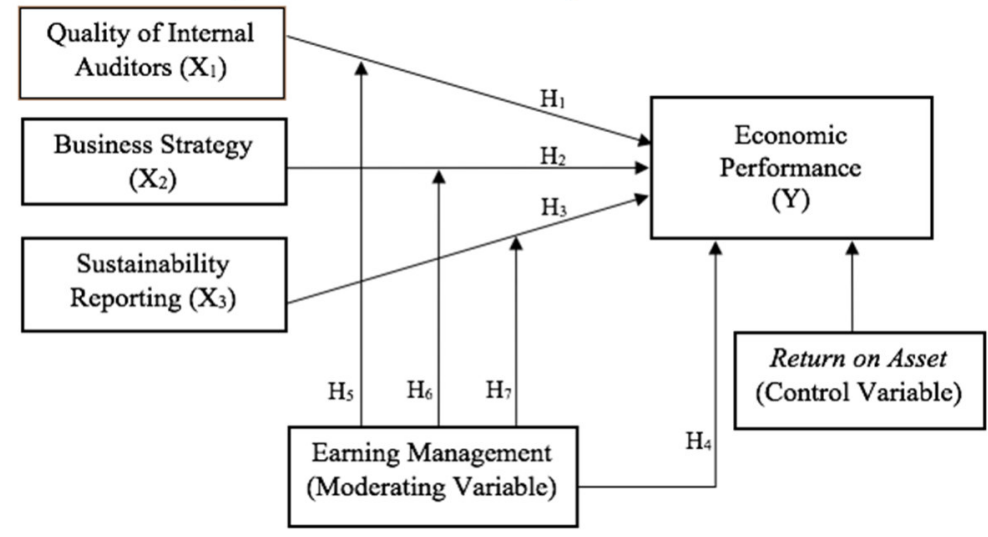

\section{Methodology}

The method used in this research is descriptive method using a quantitative approach. In this study using secondary data in the form of financial reports, annual reports and sustainability reports. Based on the level of explanation of the position of the variable, this study is associative. Associative research is a study that aims to determine the relationship between two or more variables. This study uses a regression variable for estimation purposes. The population of this study is the Kompas100 Index company listed on the Indonesia Stock Exchange (IDX). The study period includes data in 2013 until 2016 to better reflect current conditions. The sample in this study is the Kompas100 Index company which is listed on the Indonesia Stock Exchange (IDX). The sampling technique used is non probality sampling with purposive sampling method. Data collection techniques carried out by the method of documentation, namely by recording or collecting data listed on the Kompas100 Index company accessed through www.idx.com and the official website of each company sampled.

\section{Research Results and Discussion}

\subsection{Feasibility Test Model (Fit Test Model)}

The model feasibility test is conducted to determine if an independent variable is added to the model whether it significantly improves the model fit. Or in other words the research model is feasible or not to continue. The results of the model feasibility test show that the F-statistic value is 8.355806 , while F Table with the level of $\alpha=5 \%$, dfl $(\mathrm{k}-1)=4$ and $\mathrm{df} 2(\mathrm{n}-\mathrm{k})=31$ is obtained F Table value of 2.68. Thus the F-statistic (8.355806)> F Table (2.68) and the Prob (F-statistic) value is 0.000012 . It can be interpreted that together the independent variables in this study, namely the quality of internal auditors, business strategy and sustainability reporting influence economic performance with earnings management as a moderating variable. So that this model can be said to be fit and feasible to continue. The following is the output of the model feasibility test (Fit Test Model).

\begin{tabular}{|lrr|}
\hline $\begin{array}{l}\text { F-statistic } \\
\text { Prob(F-statistic) }\end{array}$ & 0.355806 & Durbin-Watson stat. 2.190686 \\
\hline
\end{tabular}

\subsection{Coefficient of Determination}

The coefficient of determination in this study is indicated by the value of Adjusted R-Square. Adjusted R-Square value is used to measure how much the dependent variable can be explained by the independent variable. The greater the Adjusted R-square results, the better because it identifies the better the independent variable in 
explaining the dependent variable. Adjusted-R-Square value of 0.627050 which indicates the suitability or compatibility of the model because the significance is greater than 0.05 , the hypothesis cannot be rejected and means the model is able to explain the relationship between the dependent variable and the independent variable. This means that changes in the ups and downs of Economic Performance (EP) can be explained by the quality of internal auditors, business strategies and sustainability reporting with earnings management as a moderating variable of $62.70 \%$, while the remaining $37.30 \%$ is explained by other variables outside the research model.

\begin{tabular}{|llll|}
\hline R-squared & 0.712296 & Mean dependent var & 18.97222 \\
Adjusted R-squared & 0.627050 & S.D. dependent var & 0.970600 \\
\hline
\end{tabular}

\subsection{Hypothesis Test (T Test)}

Partial significance testing ( $t$ test) was conducted to determine the effect of independent variables on the dependent variable. Hypothesis testing is done by comparing the significance level of 0.05 . The independent variable is said to be significant to the dependent variable if the level of significance is $<0.05$.

Before using moderating variables and control variables:

\begin{tabular}{lcccc}
\hline \hline Variable & Coefficient & Std. Error & t-Statistic & Prob. \\
\hline \hline C & 17.75138 & 0.743956 & 23.86079 & 0.0000 \\
IAQ & 0.038658 & 0.012992 & 2.975515 & 0.0055 \\
BS & 0.036448 & 0.034850 & 1.045873 & 0.3035 \\
SR & 0.412924 & 0.741055 & 0.557211 & 0.5813 \\
\hline \hline
\end{tabular}

Based on the results of the $t$ test above shows that the quality of internal auditors (IAQ) has an influence on economic performance while the business strategy (BS) does not have an influence on economic performance and sustainability reporting (SR) does not have an influence on economic performance. After using moderating variables and control variables:

\begin{tabular}{lllll}
\hline \hline Variable & Coefficient & Std. Error & t-Statistic & Prob. \\
\hline \hline C & 15.44666 & 0.961919 & 16.05817 & 0.0000 \\
IAQ & 0.047956 & 0.009621 & 4.984766 & 0.0000 \\
BS & 0.157367 & 0.044305 & 3.551940 & 0.0014 \\
SR & 0.414844 & 0.991252 & 0.418505 & 0.6789 \\
EM & 141.5330 & 71.00798 & 1.993199 & 0.0564 \\
ROA & 2.149222 & 0.995058 & 2.159897 & 0.0398 \\
IAQ*EM & -0.285568 & 1.042139 & -0.274021 & 0.7862 \\
BS*EM & -9.309344 & 3.278277 & -2.839706 & 0.0085 \\
SR*EM & 45.92237 & 69.95018 & 0.656501 & 0.5171 \\
\hline \hline
\end{tabular}

Based on the results of the $t$ test above show that:

1) Prob value. IAQ is $0.0000<0.05$ so it can be concluded that the Internal Auditor Quality variable in this study has a positive influence on economic performance (EP). Thus, H1 in this study was accepted.

2) Prob value. BS is $0.0014<0.05$ so it can be concluded that the Business strategy variable in this study has a positive influence on economic performance (EP). Thus, $\mathrm{H} 2$ in this study was accepted.

3) Prob value. SR of $0.6789>0.05$, it can be concluded that the Sustainability Reporting variable in this study has no effect on economic performance (EP). Thus, H3 in this study was rejected.

4) Prob value. EM is $0.0564<0.05$, so it can be concluded that the Earning Management variable in this study has a positive influence on economic performance (EP). Thus, $\mathrm{H} 4$ in this study was rejected.

5) Prob value. IAQ * EM is $0.7862>0.05$, it can be concluded that the Earning Management variable in this study has no influence on the relationship of the Quality of Internal Auditors to Economic Performance (EP). Thus, $\mathrm{H} 5$ in this study was rejected.

6) Prob Value. BS * EM is $0.0085<0.05$ so it can be concluded that the Earning Management variable in this study has a negative influence on the relationship of Business Strategy to Economic Performance (EP). Thus, H6 in this study was accepted.

7) Prob value. SR * EM is $0.5171>0.05$, it can be concluded that the Earning Management variable in this study has no influence on the Sustainability Report's relationship to Economic Performance (EP). Thus, H7 in this study was rejected. 


\subsection{Panel Data Regression Analysis}

The results of the calculation of panel data regression analysis in this study obtained the regression equation as follows:

$\mathrm{EP}=15.44666+0.047956 \mathrm{IAQ}+0.157367 \mathrm{BS}+0.414844 \mathrm{SR}+141.5330 \mathrm{EM}-0.285568 \mathrm{IAQ} * \mathrm{EM}-9.309344$

$$
\mathrm{BS} * \mathrm{EM}+45.92237 \mathrm{SR} * \mathrm{EM}
$$

Based on the panel data regression equation above can be interpreted that:

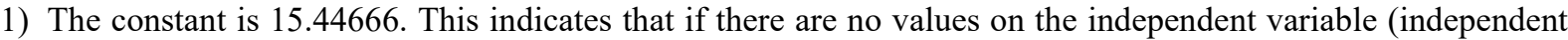
variables equal to 0 ), then economic performance has a value of 15.44666 .

2) The variable coefficient value of internal auditor quality (IAQ) is 0.047956 , meaning that each increase of 1 (one) unit of internal auditor quality will increase by 0.047956 assuming the other independent variables are constant (fixed).

3) The coefficient of the business strategy variable (BS) is 0.157367 , meaning that each increase in 1 (one) business strategy unit (BS) will increase by 0.157367 assuming that the other independent variables are constant (fixed).

4) The coefficient value of the sustainability reporting (SR) variable is 0.414844 , which means that every increase of 1 (one) unit of sustainability reporting (SR) will increase by 0.414844 assuming the other independent variables are constant (fixed)

5) The coefficient of earnings management variable is 141.5330 which means that each increase of 1 (one) profit (EM) management unit will increase by 141.5330 assuming the other independent variables are constant (fixed).

6) The coefficient value of earnings management variables moderates the quality of internal auditors (IAQ * EM) of -0.285568 which means that each increase in 1 (one) unit of earnings management moderates the quality of internal auditors (IAQ * EM) will decrease by -0.285568 assuming other independent variables are constant (permanent).

7) The coefficient of earnings management variables moderates business strategy (BS * EM) of -9.309344 which means that each increase in 1 (one) unit of earnings management moderates business strategy (BS * EM) will decrease by -9.309344 assuming other independent variables are constant (fixed )

8) The coefficient of earnings management variables moderates sustainability reporting (SR * EM) of 45.92237 which means that each increase in 1 (one) unit of earnings management moderates the sustainability report (SR * EM) will increase by 45.92237 assuming other independent variables are constant (fixed).

\subsection{Discussions}

1) Effect of Internal Auditor Quality on Economic Performance

The quality of a good internal auditor will describe the economic performance in the company will be good. It can be seen from the financial statements that have been audited by an independent auditor not separated from the contribution of an internal auditor. The quality of internal auditors is able to improve the economic performance of the company due to the quality of internal auditors is very necessary for users of financial statements if the quality of internal auditors is good will give more confidence to users of financial statements, one of which is an investor who is one of the company's stakeholders by looking at performance from the audited financial statements, the accuracy is guaranteed. This result supports the theory of stewardship, namely management within the company not only wants something that is profitable for him, but management as the manager directly wants the managed company to look good in the eyes of its stakeholders. And the results of the research data obtained that the companies that are sampled almost all have certified internal auditors. It is seen that large companies such as Astra International Tbk have the most certified internal auditors.

2) The Effect of Business Strategy on Economic Performance

It can be said that the business strategy is one of the factors that can affect economic performance caused by two types of business strategies, namely the defender and prospector. As is known if companies use a type of defender strategy that is more focused on product efficiency that is more concerned with the aggressiveness of product prices and product quality, this will affect the stability of the company which results in high fulfillment of investor expectations which investors become one of the company's stakeholders. Not only in terms of business strategy defender, which means that innovation from prospector strategy can be said to be successful for the sample companies studied supported by the results of research that large companies also made several new innovations several times. As it is known, the data collected shows that the company Kompas 100 index which is sampled uses more types of business defender strategies, this will definitely support the existing hypothesis. These results also support positive accounting theory, which lies in the attitude of management that seeks to use capabilities, accounting knowledge, accounting policies to see future views on economic performance that will occur in the future through the selection of appropriate business strategies to be carried out in the future.

3) The Effect of Sustainability Reporting on Economic Performance

The cause of sustainability reporting has no effect on one of the most dominant factors because there are still 
many companies that do not disclose the overall items contained in the actual GRI G4 guideline. In addition, the sustainability report is included in voluntary disclosure, namely voluntary disclosure, so that there are no binding regulations to require each company to issue a sustainability report.

4) The Effect of Earning Management on Economic Performance

This is contrary to the temporary hypothesis. Because of the three motivations that underlie managers do the practice of earnings management including the bonus plan hypothesis that is related to the bonus achieved by managers if the manager reaches maximum profit, even though the manager gets a bonus does not mean it cannot have a good impact on the company instead it will have a good impact, including no violation of the debt contract because the manager can convince the creditor that the company is in good condition and able to pay the debt in accordance with the agreed time so that there is no violation in the debt contract. Furthermore, managers can also convince investors that every year they can distribute dividends and convince investors that the company does not spend too much to pay taxes even though the profit conditions are not too large by playing an accounting policy. although managers practice earnings management. This is supported by positive accounting theory from Watt and Zimmerman (1989), namely there are specific hypotheses related to factors that represent manager incentives to choose accounting methods including the bonus plan hypothesis (bonus plan), the debt or equity hypothesis (debt contract) and the political cost hypothesis.

5) Effect of Internal Auditor Quality on Economic Performance with Earning Management as Moderating Variables

The cause of earnings management practices cannot affect the relationship of the quality of internal auditors to economic performance because it is related to the independence of an auditor whose independence is very much needed by the auditor to give more confidence to the users of financial statements. Then with these results it is known that the independence of internal auditors who are considered doubtful can be disputed because usually the internal auditor is still doubtful because the internal auditor works and is paid by the organization, which is likely to motivate managers to practice earnings management.

6) The Effect of Business Strategy on Economic Performance with Earning Management as Moderating Variables Because one of the factors that decrease economic performance is the opportunistic attitude of the manager or also called the practice of earnings management which in carrying out and determining a business strategy cannot be separated from the role of its managers. So if the business strategy is implemented on personal motivations of a manager, it will affect the level of economic performance within the company. This is also supported by the results of research in which the results of the sample companies studied mostly use a defender strategy where the strategy is the strategy that has the most opportunity for managers to do earnings management.

7) The Effect of Sustainability Reporting on Economic Performance with Earning Management as A Moderating Variable

This means that there is no gap for managers as direct managers to make earnings management in sustainability reporting because investors as one of the stakeholders of the company still assume that sustainability reporting disclosure is still not too important to be a measure of whether or not the company is good.

\section{Conclusions, Limitations and Recommendations}

5.1 Conclusions

Based on the results of the analysis and discussion that has been carried out using panel data regression on 9 sample companies of Kompas100 index listed on the Indonesia Stock Exchange from 2013 to 2016., the following conclusions are obtained:

1) Based on the results of the Panel Data Regression testing, it shows that the internal auditor quality variable has a positive influence on economic performance on the Kompas 100 index company listed on the Indonesia Stock Exchange.

2) The Panel Data Regression test results show that the business strategy variable has a positive effect on economic performance on the Kompas 100 index companies listed on the Indonesia Stock Exchange.

3) The Regression Data Panel test results show that the sustainability reporting variable has no effect on economic performance on the Kompas 100 index company listed on the Indonesia Stock Exchange.

4) The Panel Data Regression test results show that earnings management variables have a positive influence on economic performance on the Kompas 100 index companies listed on the Indonesia Stock Exchange.

5) The Regression Data Panel test results show that the earnings management variable moderates the relationship of internal auditor quality to economic performance and has no effect on Kompas100 index companies listed on the Indonesia Stock Exchange.

6) The Regression Data Panel test results show that the earnings management variable moderating business strategy on economic performance has a negative effect on Kompas 100 index companies listed on the Indonesia Stock Exchange. 
7) The Panel Data Regression test results show that earnings management variables moderate sustainability reporting on economic performance but the results have no effect on Kompas100 index companies listed on the Indonesia Stock Exchange.

5.2 Limitations

1) The sample of this study only examined companies that were in the compass index 100 so that this study could not be generalized.

2) This research sample examines companies that publish sustainability reports or sustainability reports so that very few companies publish which results in a small sample of companies.

3) There are still many companies that publish financial statements in foreign currencies such as USD.

4) There are companies that do not distribute dividends, which causes a limited sample of companies.

5.3 Recommendations

1) Future studies are expected to expand the research year or period to six years or more or even narrow the research period and use different research methods to obtain more authentic results.

2) Future studies should use other proxies to calculate sustainability reporting disclosures such as using the latest GRI guidelines, namely the GRI Standard. So that it can be compared between results that is better influence on the level of economic performance.

\section{References}

Arieftiara, Dianwicaksih, Sidharta Utama, Ratna Wardhani dan Ning Rahayu. Analisis Pengaruh Strategi Bisnis Terhadap Penghindaran Pajak, Bukti Empiris di Indonesia. 2013. http://lib.ibs.ac.id/materi/Prosiding/SNA\%20XVIII/makalah/146.pdf

Bentley-Goode, Kathleen A, Thomas C Omer, dan Brady J. Twedt. Does Business Strategy Impact a Firm's Information Environment?. Journal of Accounting, Auditing \& Finance, 1-25. 2017.

Donaldson, Lex dan james H. Davis. Stewardship Theory or Agency Theory: CEO Governance and Shareholder Return. Australian Journal of Management. The University of New South Wales. 16, 1, June 1991.

Eksandy, A. (2018). Metode penelitian akuntansi dan manajemen : dilengkapi contoh penelitian data sekunder dan data primer dengan analisis regresi data panel dan analisis regresi linear berganda. Tangerang: FEB UMT.

Eksandy, A. (2017). Pengaruh Carbon Accounting, Business Strategy, Dan Systematic Risk Terhadap Economic PerformancE (Studi pada Perusahaan Manufaktur yang Terdaftar di Bursa Efek Indonesia Periode 2013 2017). COMPETITIVE, 3(2), 79-90.

Gunawan, Juniati. 2015. Buku Panduan Laporan Keberlanjutan Prinsip Menentukan Isi dan Kualitas. Jakarta: Mitra Wacana Media.

Hery. 2017. Analisis Laporan Keuangan Integrated And Comprehensive Edition. Jakarta: Grasindo.

Junaidi dan Nurdiono. 2016. Kualitas Audit Perspektif Going Concern. Yogyakarta: Penerbit Andi. https://books.google.co.id/books?isbn=9792962026

Mahiswari, Raras dan Paskah Ika Nugroho. Pengaruh Mekanisme Corporate Governance, Ukuran Perusahaan dan Leverage terhadap Manajemen Laba dan Kinerja Keuangan. Jurnal Ekonomi dan Bisnis, 17 (1). 2014.

Mile, Raymond E, Charles C. Snow, Alan D. Meyer, and Henry J. Coleman Jr. Organizational Strategy, Structure and Process. The Academy of Manajement Review, Vol. 2. Issue 3. Pp. 546-562, 1978.

Pardede, Rachel Christy. Pengaruh Tingkat Pengungkapan Laporan Keberlanjutan Terhadap Manajemen Laba (Penelitian Empiris Pada Perusahaan Publik yang Tercatat Pada BEI Periode 2008-2012). Naskah Ringkas. Universitas Indonesia. 2014. http://www.lib.ui.ac.id/

Prawitt, Douglas F, Jason L. Smith, David A. Wood. Internal Audit Quality and Earnings Management. The Accounting Review, Vol. 84, No. 4, pp. 1255-1280, 2009.

Rosnidah, Ida. Model Pengukuran Kualitas Audit Internal (Penelitian Empiris Pada Perusahaan Swasta, BUMN, BUMD Dan Aparat Inspektorat Di Kota Dan Kabupaten Cirebon). Jurnal Ekonomi dan Keuangan, Vol 17, No. 3, hal. 299-317, 2013.

Sulistyanto, Sri. 2014. Manajemen Laba: Teori dan Model Empiris. Jakarta: Gransindo.

Timuriana, Tiara dan Rezwan Rizki Muhamad. Pengaruh Aset Pajak Tangguhan Dan Beban Pajak Tangguhan Terhadap Manajemen Laba (Penelitian Empiris Pada Perusahaan Manufaktur yang terdaftar di BEI periode 2010-2014). Jurnal Ilmiah Akuntansi Fakultas Ekonomi, Vol. 1, No. 2, hal. 12-20, 2015.

Wardani, Dewi Kusuma dan Pipit Dayu Isbela. Pengaruh Strategi Bisnis Dan Karakteristik Perusahaan Terhadap Manajemen Laba. JRAK, Volume 13, No. 2, Hal. 91-106, 2017.

Watts, Ross L dan Jerold L Zimmerman. Positive Accounting Theory: A Ten Year Perspective. The Accounting Review, Vol. 65, No. 1, hal. 131-156, 1990.

Widarto, Danny dan Rina Mudjiyanti. Pengaruh Environmental Performance dan Environmental Disclosure Terhadap Economic Performance. Universitas Muhammadiyah Purwokerto. 2015. 
Widyasari, Permata Ayu, Senny Harindahyani dan Felizia Arni Rudiawarni. Strategi Bisnis dalam Praktik Manajemen Laba pada Perusahaan Manufaktur di Indonesia (Penelitian Empiris Pada Perusahaan Manufaktur yang Terdaftar di BEI Periode 2011-2014). Jurnal Keuangan dan Perbankan, Vol. 21, No. 3, hal. 397-411, 2017.

Wijayanti, Rita. Pengaruh Pengungkapan sustainability Report terhadap Kinerja Keuangan perusahaan. Syariah Paper Accounting FEB UMS, 2016.

Wulandari, Ratna Dian dan Erna Hidayah. Pengaruh Environmental Performance dan Environmental Disclosure Terhadap Economic Performance (Studi pada Perusahaan Manufaktur yang Terdaftar di Bursa Efek Indonesia Periode 2009-2011). EKBISI Vol. VII, No. 2, Juni 2013, hal. 233-244. 